\title{
Income inequality in Brazil: What has changed in recent years?
}

\author{
Helder Ferreira de Mendonça and Diogo Martins Esteves
}

ABSTRACT

\begin{abstract}
This paper provides empirical evidence to assess the impact of socioeconomic and political variables on different measures of income inequality based on the 27 units of the Brazilian federation in the period from 1999 to 2008. The Brazilian experience is a good example for understanding the income inequality policies in developing countries. The findings suggest that the improvement observed along the period under analysis is a result of the combination of increased trade openness, technological and financial development, a reduction in the unemployment rate, the adoption of social policies that imply a direct effect on the poorest families and the adoption of mechanisms against corruption.
\end{abstract} models, Brazil at the National Council for Scientific and Technological Development (CNPq). helderfm@hotmail.com Diogo Martins Esteves is a $\mathrm{PhD}$ candidate at the Department of Economics at the Fluminense Federal University. diogomartinse@yahoo.com.br 


\section{I}

\section{Introduction}

Analysing the main causes of income inequality is essential for uncovering ways to mitigate it. A traditional question in the literature on income inequality is how an increase in trade openness affects the income distribution. In developing economies, where inequality is high and unskilled labour is predominant, an increase in trade openness may induce an increase in exports, which, in turn, reduces income inequality (Easterly, 2005). As suggested by Nissanke and Thorbecke (2006), an increase in openness is usually accompanied by an increase in foreign direct investment (FDI) and the diffusion of new technologies and know-how. This should generate an increase in productivity and output that would be capable of increasing wages and employment. ${ }^{1}$

The globalization process also affects the income distribution. According to Adams (2008), the use of patents as a mechanism for the defence of intellectual property rights and for stimulating innovations in developing economies should imply a reduction in inequality. The same result is observed by Acemoglu and Newman (2002). According to this view, in developing economies, unskilled labour is abundant, and technological progress thus improves productivity. As a result, knowledge spillovers could increase the income of unskilled workers (see Fang, Huang and Wang, 2008), fostering a better income distribution.

Unemployment is undoubtedly the main cause of poverty. Blinder and Esaki (1978) first described the relation between unemployment and income inequality. The basic idea is that unemployment tends to affect the less skilled and the low-paid more than other groups. Thus, unemployed people tend to be concentrated in the lower end of the income distribution (Martínez, Ayala and Ruiz-Huerta, 2001).

The success of social polices is controversial in literature. There is empirical evidence that increases in the minimum wage are an important tool for combating income inequality (Lemos, 2009). Moreover, as pointed out by Engel, Galetovic and Raddatz (1999) and Goñi, López and Servén (2011), government transfers are an efficient mechanism for reducing inequality. In contrast, Feldstein (1974) argues that social spending

1 For an empirical analysis contrary to the argument that trade openness reduces income inequality, see Meschi and Vivarelli (2009). (welfare, social security and so forth) increases income inequality, to the extent that high income families receive a disproportionately large percentage of the benefits (Forteza and Rossi, 2006).

Another relevant issue is the effect of political competition. The study of the relationship between social and political variables goes back to Adelman and Morris (1965). As observed by Rupasingha and Goetz (2007), greater political competition leads to a lower level of poverty. Corruption is also connected to income inequality: an increase in corruption causes greater income inequality (Gupta, Davoodi and AlonsoTerme, 2002; Dincer and Gunalp, 2008; Apergis, Dincer and Payne, 2010).

This paper addresses the above issues in the context of the Brazilian case. Brazil is a leading emerging economy, with the seventh largest economy in the world, and it has recently been successful in decreasing income inequality. The recent period has been marked by a combination of consolidated democracy, a stable macroeconomic environment and the adoption of several anti-poverty initiatives by the government (for example, the implementation of the Bolsa Família conditional cash transfer programme and successive real increases in the minimum wage).

Like the United States, Brazil is characterized by vast geographical differences. Hence, the first step in this study is to observe the behaviour of the main factors that can explain income inequality for each region, identifying where each factor is most effective. The second step is to present empirical evidence using a dynamic panel data framework that covers the 27 units of the Brazilian federation in the period from 1999 to 2008. In short, the main objective of this research is to provide empirical evidence to assess the impact of socioeconomic and political variables on different measures of income inequality.

The remainder of this paper is organized as follows. Section II describes the data used in this research and provides a regional analysis for the Brazilian case. Section III presents empirical evidence, based on panel data analysis, on the impact of socioeconomic and political variables on different measures of income inequality for the 27 units of the federation in the period from 1999 to 2008. Section IV presents our conclusions. 


\section{II}

\section{Income inequality: regional analyses}

In 1999, Brazil adopted a flexible exchange rate regime, inflation targeting and a primary fiscal surplus. The resulting macroeconomic stabilization has fostered an improvement in the income distribution. In this study, we follow the literature on income inequality in considering a number of socioeconomic variables (Roine, Vlachos and Waldenström, 2009; Easterly, 2005; Acemoglu, 2002) and political variables (Gupta, Davoodi and Alonso-Terme, 2002; Alt and Lassen, 2010). The fact that Brazil has a continental dimension implies that regional differences must also be taken into account. Hence, this section shows the regional behaviour of the variables used in the empirical model for the period from 1999 to $2008 .^{2}$

For decades, income inequality in Brazil was very high in comparison with other countries (Gasparini, 2003). Inequality began decreasing, however, in the late 1990s. To delineate this trend and test for robustness, we consider three indicators:

- The Gini inequality index, which measures the inequality of a distribution on a scale of zero (total equality) to one (maximum inequality). This coefficient is calculated using information available from the Monthly Employment Survey carried out by the Brazilian Geographical and Statistical Institute (IBGE).

- The Theil index, which measures economic inequality on a scale of zero (total equality) to one (maximum inequality). This index is calculated based on information from the IBGE Monthly Employment Survey.

- The ratio of the income of the richest $10 \%$ of the total population to the income of the poorest $40 \%$ (the 10:40 ratio). This index is calculated based on information from the IBGE National Household Survey. This ratio is readily interpretable as expressing the income of the rich as multiples of that of the poor.

2 The period under analysis ends in 2008 due to the lack of data after that date.
The behaviour of these indicators over time shows that living standards have improved in all regions, with all indicators falling at the end of the period. Figure 1 shows that the northeast region has the worst level of inequality for all indices throughout most of the period (that is, the line corresponding to this region is the farthest from the centre in all three panels of the figure), but the region recorded an improvement at the end of the period, when the midwest region moved into the worst position. The midwest region had the worst performance in reducing inequality over time. Between 1999 and 2008 , the Gini index fell by only $4.3 \%$, the Theil index by $8.1 \%$, and the $10: 40$ ratio by $15.3 \%$. The region with the best performance is the south, which not only recorded the lowest levels of inequality throughout the period, but also saw the steepest decline in inequality (12\% decrease in the Gini index, $22.8 \%$ in the Theil index, and $32.4 \%$ in the $10: 40$ ratio).

With regard to economic variables, trade openness is often cited as being relevant for analysing income inequality (Rodrik, 1997; Easterly, 2005; Nissanke and Thorbecke, 2006). One reason is that the relation between the distributional framework and trade openness depends partly on the extent that productive factors are used in the production of a country's main products. Differences among countries can be magnified by differences in tax and labour laws, but this effect is negligible in the analysis of the states of the Brazilian federation, since they are all subject to the same legal code. This paper therefore uses the following indicator of trade openness between the states and foreign nations, based on data from the Ministry of Development, Industry and Foreign Trade (MDIC) and the Central Bank of Brazil (СBB): OPEN = (total imports + total exports)/GDP.

As shown in figure 2, the midwest region again had the worst performance over time, but its trade openness improved considerably after 2002, and the region surpassed the northeast in 2008 . The southeast region recorded the most stable performance among the regions, consistently holding an intermediate position. The north was the most openness, but the south has approached this level over time. 
FIGURE 1

Brazil, five regions: inequality indicators, 1999-2008

A. Gini Index

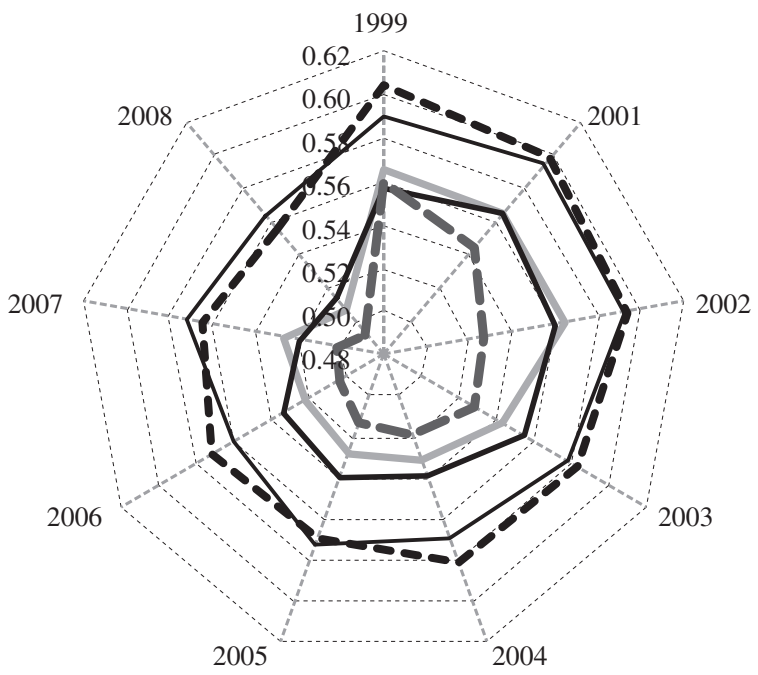

B. Theil Index

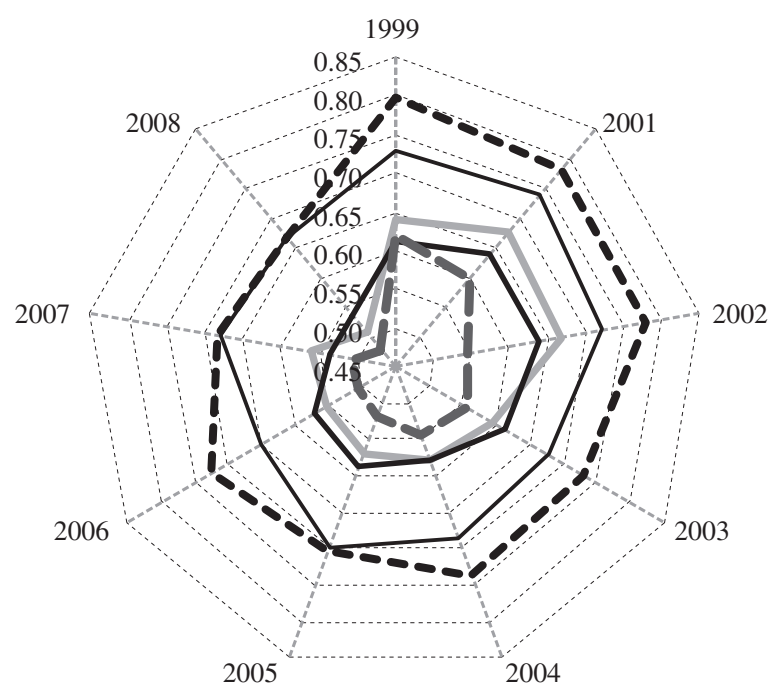

C. $10: 40$ ratio

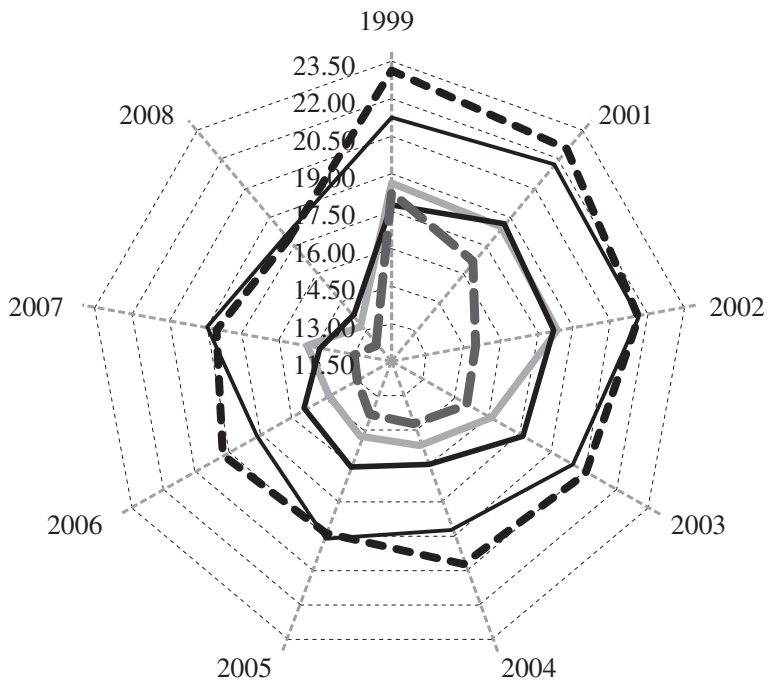

North

- Midwest

Southeast

$\longrightarrow$ South

Source: Brazilian Geographical and Statistical Institute (IBGE). 


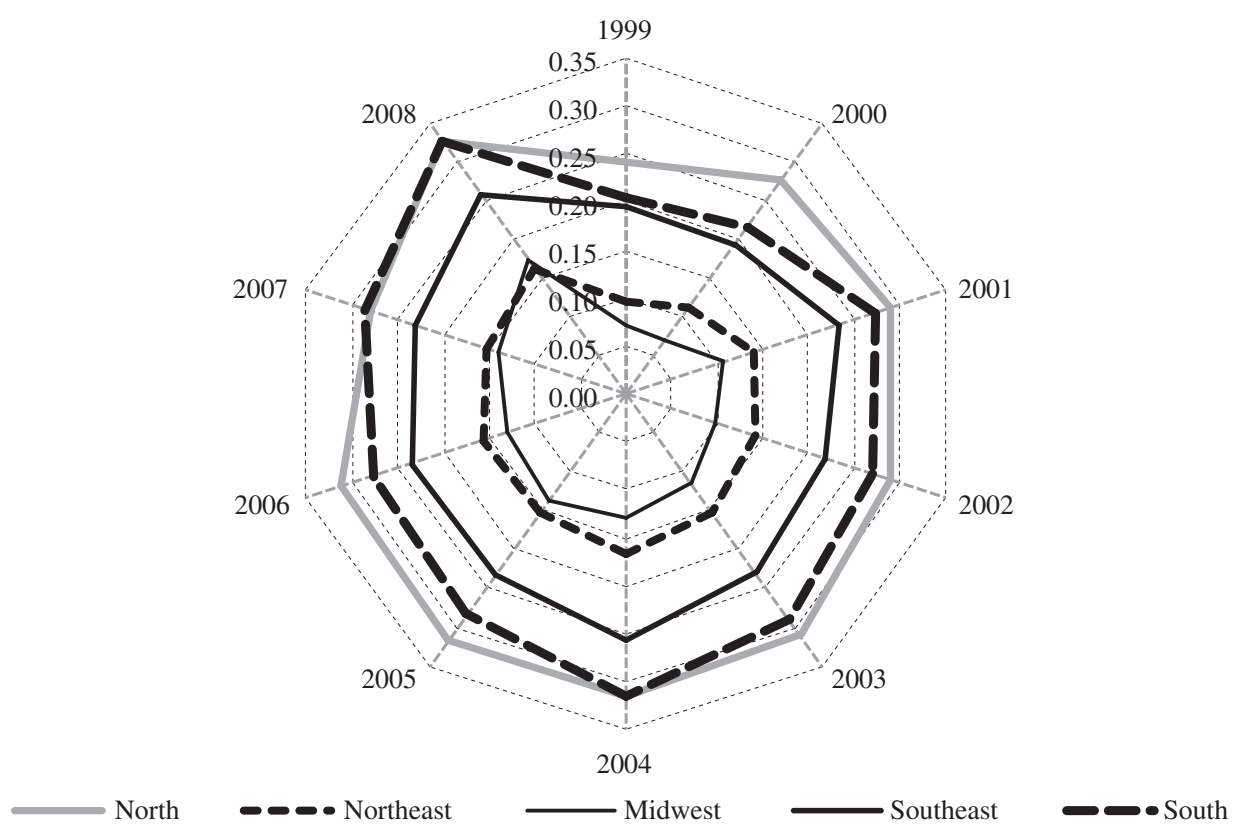

Source: Ministry of Development, Industry and Foreign Trade (MDIC) and Central Bank of Brazil.

Note: OPEN is the sum of imports and exports divided by gross domestic product (GDP).

Another key variable in the analysis of income inequality is technological development (Acemoglu and Newman, 2002; Madsen, 2007; Fang, Huang and Wang, 2008). In this analysis, we us a proxy for technological development, namely, the ratio of patents granted in each state to total patents granted by Brazil in a given year (PAT), based on data from the National Institute of Industrial Property. ${ }^{3}$ This proxy makes it possible to observe the average technological growth of the country. However, because the variable is a ratio, it could decrease even if the number of patents increases in a given state, whenever the state's growth rate is lower than the average growth rate for the country as a whole. To facilitate the interpretation of the results, the proxy is normalized to a range from 0 to 1 . Figure 3 shows that a large share of technological development is concentrated in the southeast region, whereas the north and midwest regions are negligible. The path of this indicator did not change considerably among the regions during the period.

Another relevant variable for income inequality is financial development (Greenwood and Jovanovic, 1990; Galor and Zeira, 1993; Aghion and Bolton,

3 In 2007 and 2008, we excluded total patents issued from abroad from those attributed to Rio de Janeiro.
1997; Claessens and Perotti, 2005). As observed by Kumar (2005), individuals with access to financial services can safeguard against periods of low income or unexpected fluctuations in income, which improves resource allocation. Furthermore, a developed financial system implies that people living in poverty have access to financial services. In Brazil, an overwhelming majority of clients in the banking system use passbook savings accounts. ${ }^{4}$ Therefore, the proxy used here for financial development (FD) is the total balance of savings in a given state in December of each year divided by the state's gross domestic product (GDP) (in real 2000 terms), based on banking statistics provided by the Central Bank of Brazil. Figure 4 shows that this indicator fell in all regions in the early years of the sample. The southeast had the best performance over time, but the south and northeast regions posted a strong recovery toward the end of the period.

Between 1999 and 2008, the Brazilian government adopted several initiatives that, together with a good macroeconomic environment, generated a significant impact on the inequality level and the labour market. Key measures included successive real increases in the

\footnotetext{
4 According to Kumar (2005), 97\% of all clients in Brazil hold their money in the form of passbook savings accounts.
} 
FIGURE 3

Brazil, five regions: technological development (PAT), 1999-2008
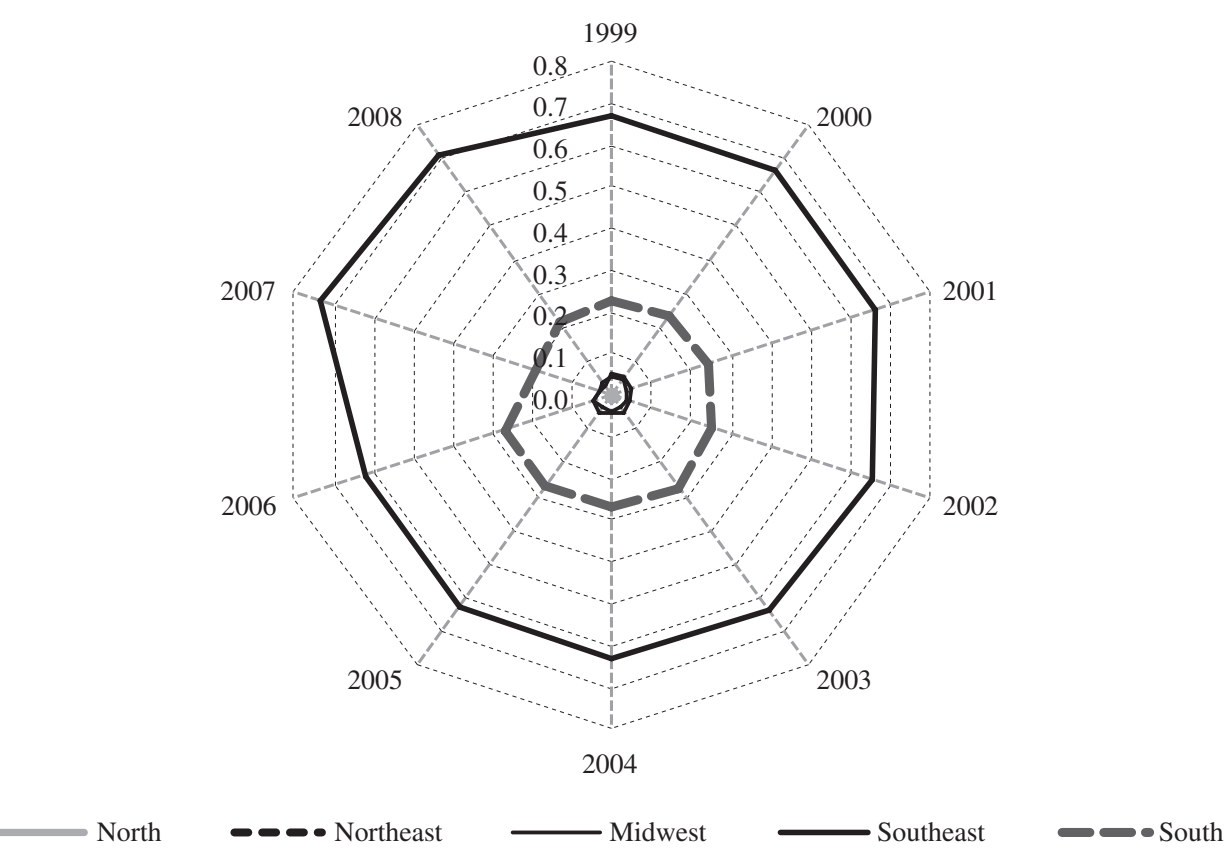

Source: National Institute of Industrial Property.

Note: PAT is the ratio of patents granted in each state to total patents granted by Brazil.

FIGURE 4

Brazil, five regions: financial development (FD), 1999-2008
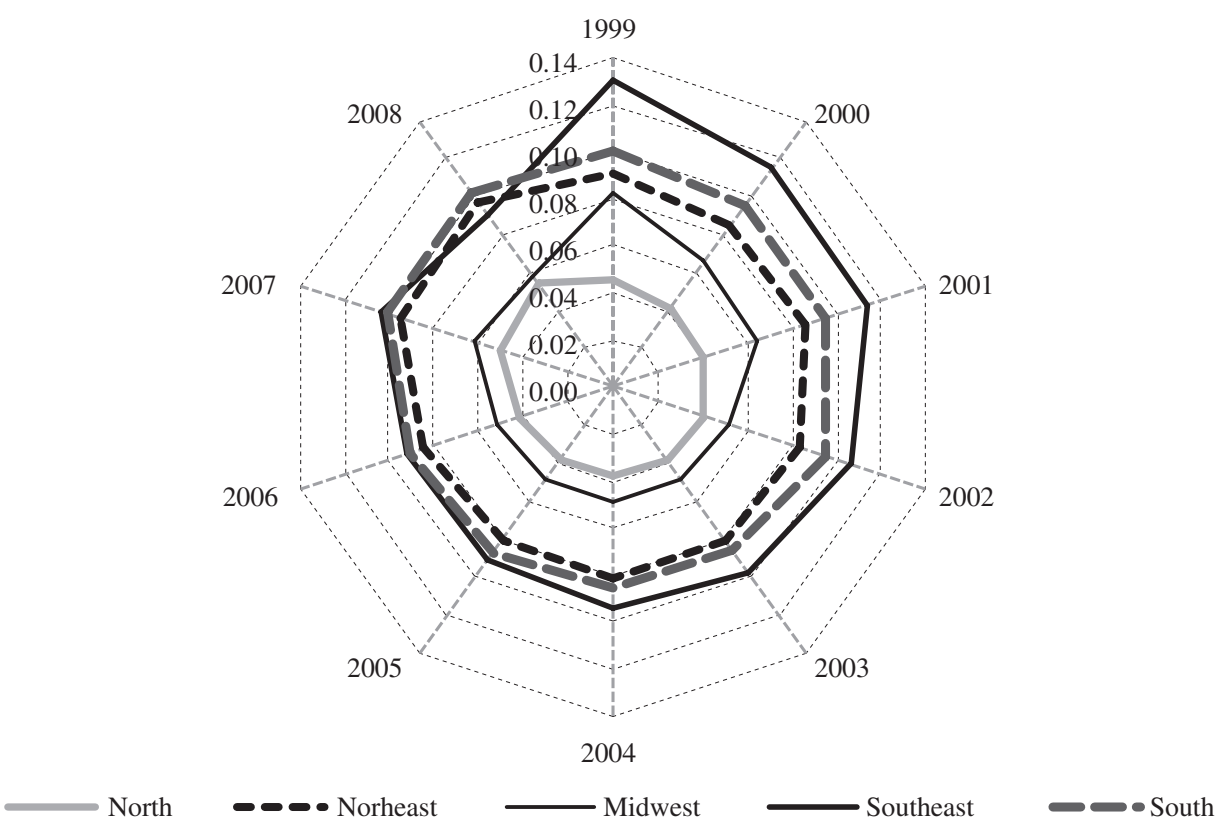

Source: Central Bank of Brazil.

Note: FD is total savings divided by gross domestic product (GDP). 
minimum wage and the implementation of the Bolsa Família conditional cash transfer programme. With regard to the minimum wage, a federal law sets the floor, and each state can then set its minimum wage at or above the floor. Increases in the minimum wage not only affect minimum wage workers, but also pass through to a range around it in both the formal and informal sectors of the economy (without increasing the unemployment rate) (Lemos, 2009). Moreover, the effects of the increase are not limited to wages, but also influence pension benefits and unemployment insurance. ${ }^{5}$ A change of this variable thus has a considerable impact on the population's income. To capture these effects, we look at the annual variation of the minimum wage (MW) in each state (in real 2000 terms). Figure 5 shows the path for the variation in the minimum wage floor defined by the federal government and the effective minimum wage in states that adopted a different value. In general, after a state adopts a minimum wage above the national floor, the trend is for the state to follow the behaviour of the national minimum wage.

Unemployment is another critical variable in the analysis of inequality. We therefore include the unemployment rate by state (UNE) in both the formal and informal sectors, using data from the Institute of

5 According to Ministry of Labour and Employment, these categories had a direct impact on over $8.4 \%$ of the population in 2003 .
Applied Economic Research (IPEA). Figure 6 shows that all regions recorded a decline in the unemployment rate in the sample period, but with significant differences. The unemployment rate in the northeast region declined only $3.5 \%$ in 10 years, representing the worst performance. In contrast, the unemployment rate declined $38 \%$ in the south. The southeast region continued to have the highest unemployment rate in the country, but it ended the period near the levels observed in the northeast and idwest regions (down $27.4 \%$, for the second best performance).

A centrepiece of the Brazilian government's antipoverty policies in the period under analysis was the Bolsa Família conditional cash transfer programme, initiated in 2004. Under the programme, poor families with children receive an average of $\mathrm{R} \$ 70.00$ (about US\$ 40.00) in direct transfers, on the condition that they commit to keeping their children in school and taking them for regular health checks. Through this social initiative, the Ministry of Social Development and Hunger Alleviation (MSD) reached a major portion of the country's low-income population (more than 46 million people).

The Bolsa Família programme reaches only a share of the population that has a per capita income of less than R\$ 140.00 per month. Therefore, the ratio of Bolsa Família beneficiaries to the total population can be used to capture the real weight of the programme on the total population. In contrast, other possible measures, such

FIGURE 5

Brazil, four states: annual variation in the minimum wage (MW), 1999-2008

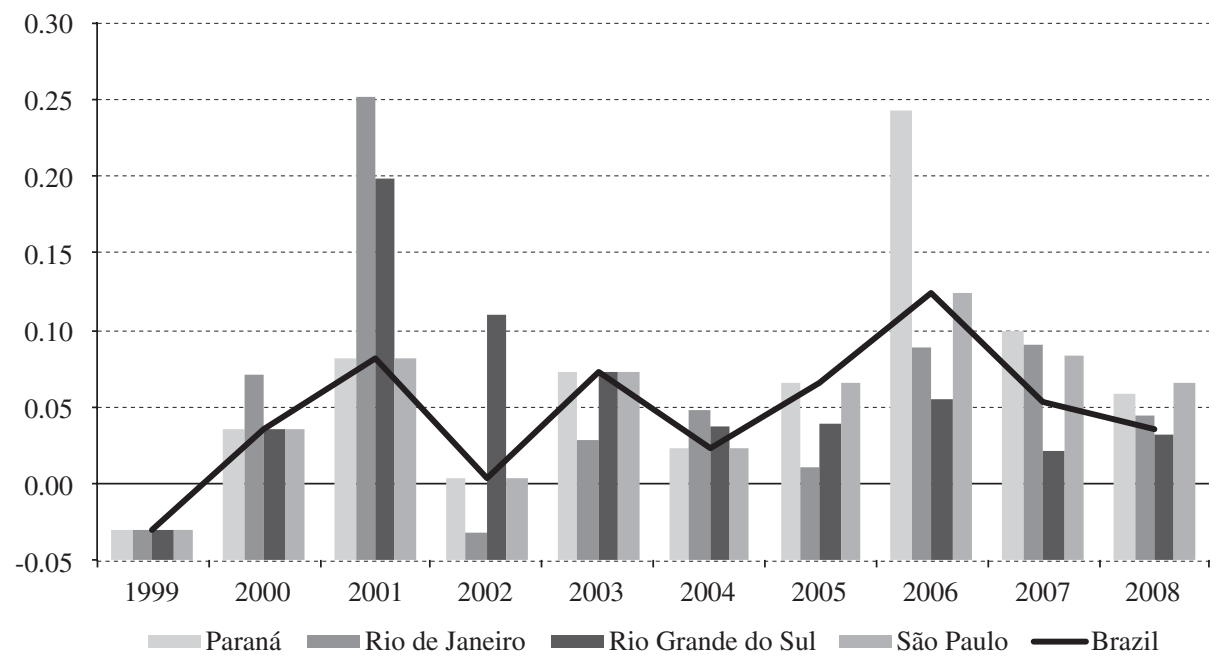

Source: Ministry of Labour and Employment and state laws.

Note: Mw is the annual variation of the minimum wage divided by the minimum wage. 
FIGURE 6

Brazil, five regions: unemployment rate (UNE), 1999-2008

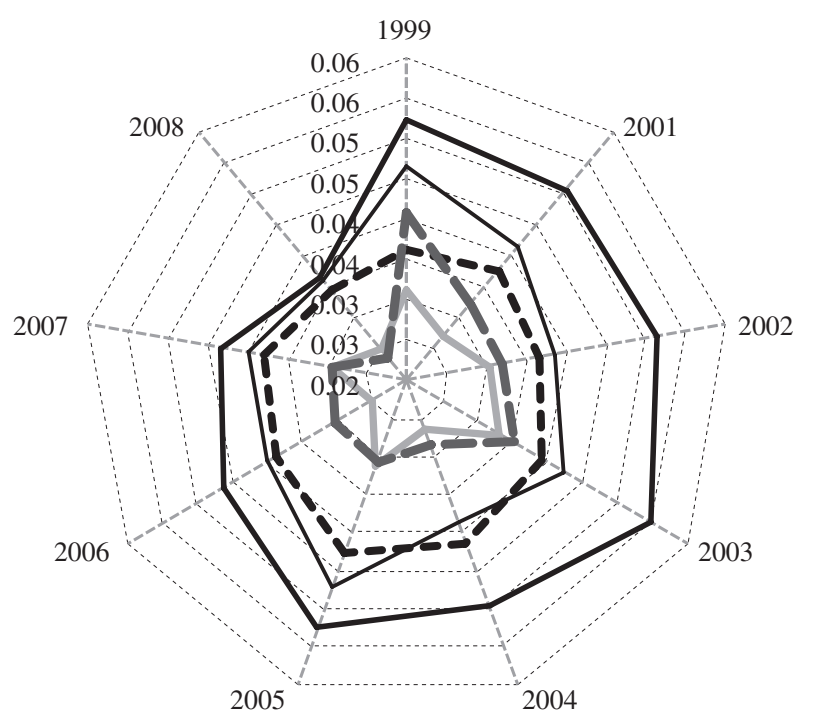

North $\bullet-\bullet$ Northeast

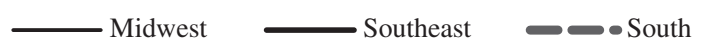

Source: Institute of Applied Economic Research (IPEA).

Note: UNE is the unemployment rate (formal and informal).

as the ratio of Bolsa Família beneficiaries to the poor population, contain some distortions. In regions where there are fewer poor, an increase in the number of Bolsa Família recipients will create a huge impact on the ratio of programme beneficiaries to the poor population, while it falls short in capturing the effect on the income distribution of the total population. Hence, to capture the inequality effect, we use the ratio of the number of Bolsa Família beneficiaries to the total population of each state (BF), based on data from the Institute of Applied Economic Research (IPEA).

As shown in figure 7, the first three years of the programme indicate growth in all regions. Since the programme targets poor families, it is not surprising that the south had the lowest growth in the period (18\%). In contrast, the north recorded an increase of $93.5 \%$, and the northeast had the largest BF.

We included some political variables in this analysis to address the possibility that political factors influence the income distribution. According to Levitt and Poterba (1999) and Rupasingha and Goetz (2007), a democratic system correlates with a lower poverty level. We therefore look at changes in political power in the Brazilian states. In the period from 1999 to 2008 , there were three electoral mandates in the states (1999-2002, 2003-2006 and 2007-2010). Our political change indicator (PC) is a dummy variable that takes a value of one (1) if the previous government's party is different from the current government's party and zero (0) otherwise.

Table 1 shows that it is common for a political party to stay in power for two or more consecutive mandates. Only six states deviated from this phenomenon. In particular, the states in the south underwent two (Paraná and Santa Catarina) and three (Rio Grande do Sul) political changes in the period. Since the south has the best indices of income inequality, this trend could support the argument that democracy reduces inequality. However, it is not possible to confirm this trend for the other regions.

To assess the impact of a state's social spending (that is, welfare and social security), we calculated the ratio between direct transfers to citizens and the state's GDP (SOC), based on data from the Ministry of Finance. With the exception of the northeast region, all regions recorded a decline in social spending in the period (see figure 8). One reason for this trend is the Fiscal Responsibility Act approved by the Brazilian Congress in 2000, which limits states' expenses to $60 \%$ of current net revenue for its personnel.

Finally, we look at the effect of corruption on income inequality (Gupta, Davoodi and AlonsoTerme, 2002; Alt and Lassen, 2010). According 
FIGURE 7

Brazil, five regions: ratio of Bolsa Familia beneficiaries to the regional population (BF), 1999-2008

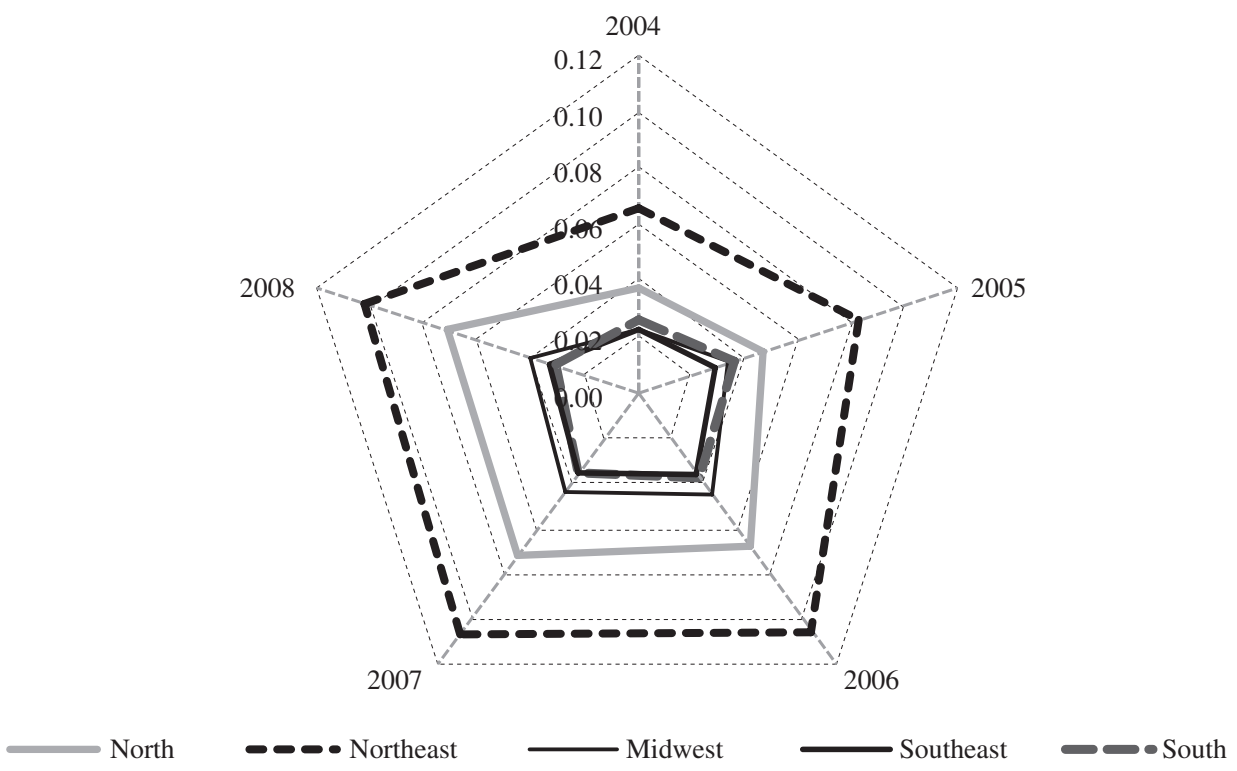

Source: Ministry of Social Development and Hunger Alleviation.

Note: BF is the ratio of the number of Bolsa Família beneficiaries to the total population.

TABLE 1

Brazil, five regions: episodes of political change (PC), 1999-2008

\begin{tabular}{|c|c|}
\hline No. of changes & States and Federal District \\
\hline 0 & São Paulo (SE) \\
\hline 1 & $\begin{array}{l}\text { Acre (N), Amapá (N), Bahia (NE), Ceará (NE), Maranhão (NE), Pará (N), Paraíba (NE), Piauí (NE), Rio Grande do } \\
\text { Norte (NE) }\end{array}$ \\
\hline 3 & Amazonas (N), Espírito Santo (SE), Rio de Janeiro (SE), Rondônia (N), Roraima (N), Rio Grande do Sul (s) \\
\hline
\end{tabular}

Source: Institute of Applied Economic Research (IPEA).

Note: $\mathrm{SE}=$ Southeast $; \mathrm{S}=$ South $; \mathrm{N}=$ North $; \mathrm{NE}=$ Northeast $; \mathrm{MW}=$ Midwest .

to the corruption perceptions index published by Transparency International, Brazil's index worsened considerably from 1999 to 2008 , falling from 45th to 80 th in the least corruption ranking. For this study, we consider the variation of the corruption index (CORR) built by Boll (2009), based on the weighted average of socioeconomic variables (state population and GDP $=0.33$ ) and the number of processes deemed illegal by the Brazilian Court of Audit (0.66) according to the Annual Budget Law. The index ranges from zero (0) (least corrupt) to one (1) (most corrupt). Figure 9 depicts the average corruption by state in the period. The three highest indices were all in the northeast region (Maranhão, Piauí and Bahia), while the two lowest indices were in the south (Rio Grande do Sul and Santa Catarina). 
FIGURE 8

Brazil, five regions: social spending (SOC), 1999-2008

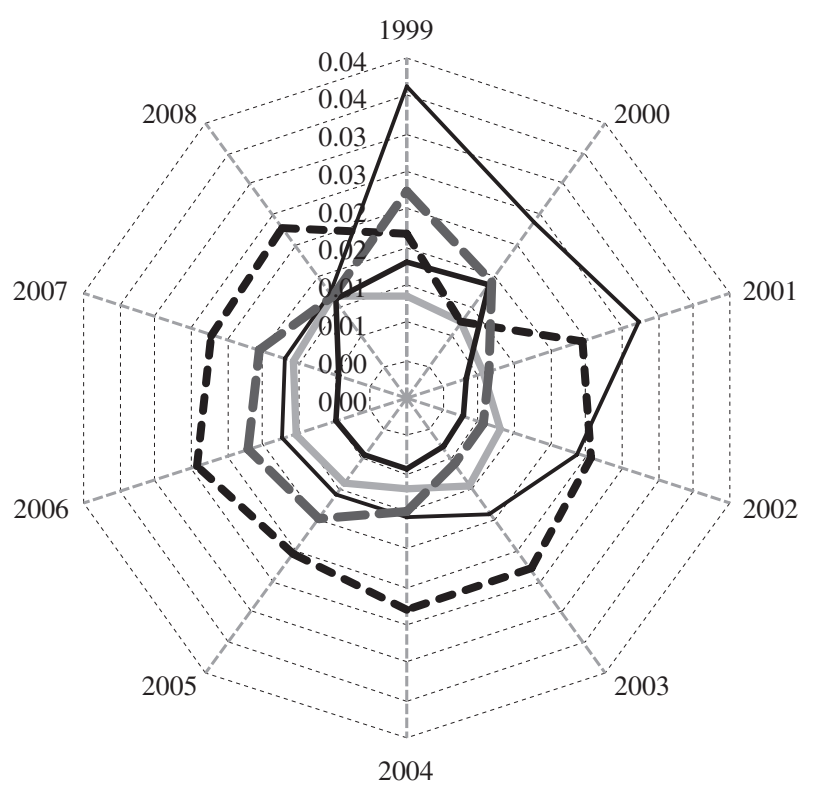

Source: Ministry of Finance.

Note: SOC is the ratio between direct transfers to citizens and the state's GDP.

FIGURE 9

Brazil: average state and Federal District corruption (CORR), 1999-2008

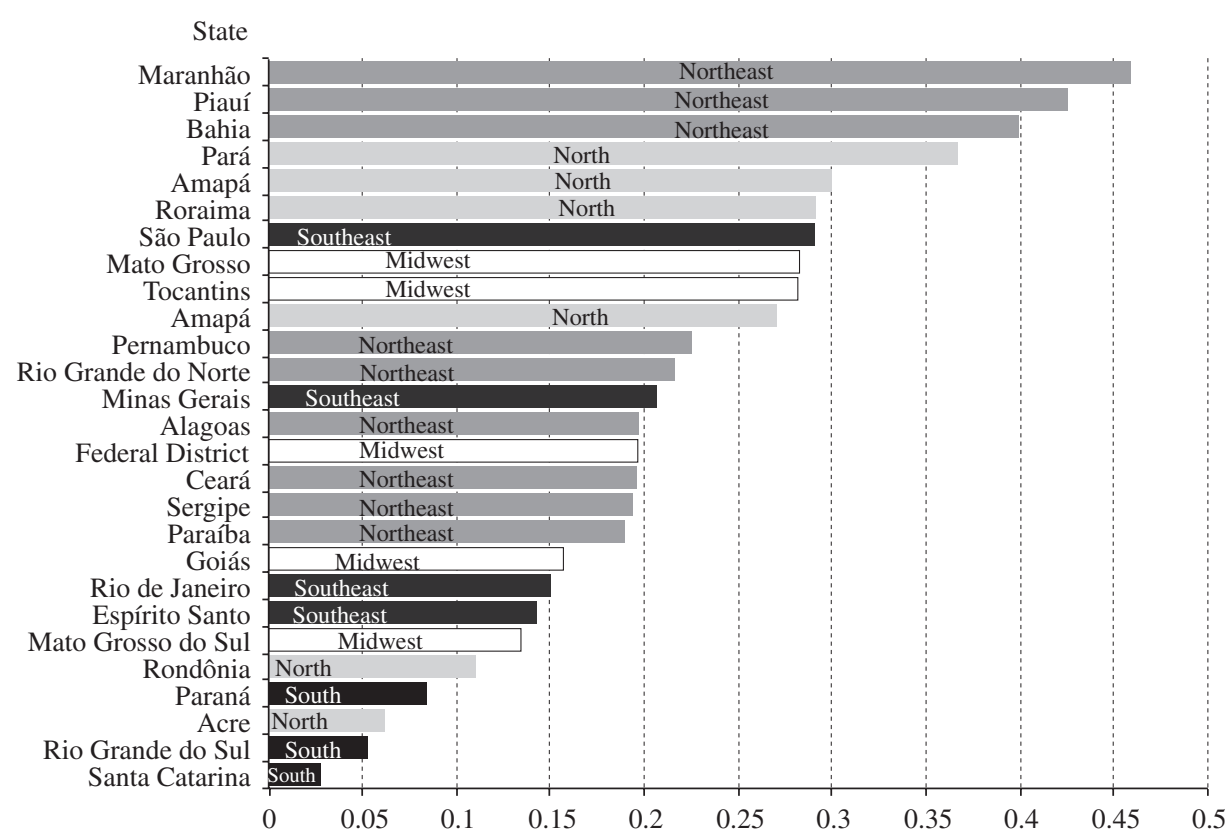

Source: J.L.S. Boll, “A corrupção governamental no Brasil: construção de indicadores e análise da sua incidência relativa nos estados brasileiros", Brasilia, 2010 [online] http://www.cgu.gov.br/concursos/Arquivos/5_ConcursoMonografias/MH-profissionais-jose-luis-serafiniboll.pdf.

Note: horizontal axis is the average of the corruption index. 


\section{III}

\section{Empirical evidence}

The variables presented in the previous section provide a total of 270 observations (annual frequency) for the 26 Brazilian states plus the Federal district in the period 1999-2008. This section presents empirical evidence using a generalized method of moments (GMM) estimator for panel data analysis (table 2 shows the descriptive statistics). According to Arellano and Bond (1991), one advantage of using the GMM dynamic panel data method is that in addition to eliminating the non-observable effects on the regressions, the estimates are reliable even in the case of omitted variables. In particular, the use of instrumental variables allows a more consistent estimation of parameters, even in the case of endogeneity in explanatory variables and in the presence of measurement errors (Bond, Hoeffler and Temple, 2001).

Traditional econometric models hypothesize that the error term is not correlated with its estimators. In cases where the estimators are correlated with the error term, there is an endogeneity problem, and the regression results are inconsistent. Wooldridge (2001) identifies three hypotheses for the existence of endogenous variables: omitted variables, measurement error and simultaneity problems. The empirical model developed in this study is subject to those problems. For example, trade openness can reduce income inequality, which, in turn, can induce an increase in imports, thereby changing trade openness.

TABLE 2

Descriptive statistics

\begin{tabular}{lccccc}
\hline Variable & Mean & Median & Maximum & Minimum & Std. deviation \\
\hline Gini index & 0.5538 & 0.5545 & 0.6545 & 0.4486 & 0.0375 \\
Theil index & 0.1788 & 0.1739 & 0.3266 & 0.0954 & 0.0412 \\
10:40 ratio & 0.6376 & 0.6262 & 1.0369 & 0.3875 & 0.1106 \\
OPEN & 0.1707 & 0.1270 & 0.6051 & 0.0023 & 0.1446 \\
PAT & 0.0370 & 0.0043 & 0.6000 & 0.0000 & 0.0940 \\
FD & 0.0751 & 0.0795 & 0.1419 & 0.0282 & 0.0264 \\
MW & 0.0493 & 0.0535 & 0.2511 & -0.1411 & 0.0543 \\
UNE & 0.0419 & 0.0406 & 0.0801 & 0.0180 & 0.0126 \\
BF & 0.0338 & 0.0237 & 0.1208 & 0.0000 & 0.0375 \\
SOC & 0.0196 & 0.0195 & 0.0737 & 0.0017 & 0.0103 \\
CORR & 1.0955 & -0.0074 & 40.5000 & -1.0000 & 4.1627 \\
\hline
\end{tabular}

Source: prepared by the authors.

A general solution to the problem of endogeneity is the use of instrumental variables. GMM models permit the use of instruments that are sequentially exogenous, which avoids the endogeneity problem. Arellano and Bond (1991) proposed the use of a first-differenced GMM estimator for panel data as a way of eliminating non-observable effects. However, Alonso-Borrego and
Arellano (1998) and Blundell and Bond (1998) show that the first-differenced GMM estimator is biased for large and small samples and has low accuracy. Furthermore, the use of lags can create weak instruments (Staiger and Stock, 1997). Blundell and Bond (1998) therefore recommend the use of the system GMM panel data estimation method instead of first-differenced GMM. As 
proposed by Arellano and Bover (1995) and Blundell and Bond (1998), we combine regressions in levels and first differences (see Bond, Hoeffler and Temple, 2001).

To check the instruments in the models, we performed the Sargan test of overidentifying restrictions, as suggested by Arellano (2003). We also applied White's heteroskedasticity-consistent covariance matrix on the regressions, as well as the test for second-order serial correlation (m2) proposed by Arellano and Bond (1991). We did not perform unit root tests, as one premise of system GMM models is the non-correlation of the first difference of endogenous regressors.

For the purpose of finding empirical evidence of the effect of the variables described in the previous section on inequality indices (the Gini index, the Theil index and the 10:40 ratio), we considered two sets of system GMM models using panel data. The first set —equations (1) to (4) - includes the traditional variables (OPEN, PAT and $\mathrm{FD}$ ) and socioeconomic variables (MW, UNE and $\mathrm{BF}$ ). The second set —equations (5) to (7)—also considers OPEN, PAT and FD, but includes variables that are subject to some political interference (PC, SOC and CORR). Hence,

$$
\begin{aligned}
& X_{i, t}=\beta_{0} X_{i, t-1}+\beta_{1} \text { OPEN }_{i, t}+\beta_{2} P A T_{i, t}+ \\
& \beta_{3} F D_{i, t}+\mu_{i, t}^{X, 1} \text {; } \\
& X_{i, t}=\beta_{4} X_{i, t-1}+\beta_{5} O P E N_{i, t}+\beta_{6} P A T_{i, t}+ \\
& \beta_{7} F D_{i, t}+\beta_{8} M W_{i, t}+\mu_{i, t}^{X, 2} \text {; } \\
& X_{i, t}=\beta_{9} X_{i, t-1}+\beta_{10} O P E N_{i, t}+\beta_{11} P A T_{i, t}+ \\
& \beta_{12} F D_{i, t}+\beta_{13} U N E_{i, t}+\mu_{i, t}^{X, 3} \text {; } \\
& X_{i, t}=\beta_{14} X_{i, t-1}+\beta_{15}{ }^{O P E N_{i, t}}+\beta_{16} P A T_{i, t}+ \\
& \beta_{17} F D_{i, t}+\beta_{18} B F_{i, t}+\mu_{i, t}^{X, 4} \text {; } \\
& X_{i, t}=\beta_{19} X_{i, t-1}+\beta_{20} O P E N_{i, t}+\beta_{21} P A T_{i, t}+ \\
& \beta_{22} F D_{i, t}+\beta_{23} P C_{i, t}+\mu_{i, t}^{X, 5} \text {; } \\
& X_{i, t}=\beta_{24} X_{i, t-1}+\beta_{25} O P E N_{i, t}+\beta_{26} P A T_{i, t}+ \\
& \beta_{27} F D_{i, t}+\beta_{28} S O C_{i, t}+\mu_{i, t}^{X, 6} \text {; } \\
& X_{i, t}=\beta_{29} X_{i, t-1}+\beta_{30} O P E N_{i, t}+\beta_{31} P A T_{i, t}+ \\
& \beta_{32} F D_{i, t}+\beta_{33} \operatorname{CORR}_{i, t}+\mu_{i, t}^{X, 7}
\end{aligned}
$$

where $\mu_{i, t}^{X} \sim N\left(0, \sigma^{2}\right)$, and $X$ is the inequality index (the Gini index, the Theil index or the 10:40 ratio).

Tables 3, 4 and 5 show the estimation results for the models. All regressions accept the null hypothesis in the Sargan tests, so the overidentifying restrictions are valid. Furthermore, serial autocorrelation tests reject the hypothesis of the presence of serial autocorrelation.

We find that independent of the inequality indicator used in the estimations, the coefficient on the variable OPEN is negative and statistically significant in all specifications. This result is consistent with the argument that an increase in openness is an important mechanism for reducing income inequality. The coefficients on PAT and FD are also negative, although they are not always statistically significant; this suggests that technological and financial development contribute to lowering income inequality.

The MW coefficients are negative and statistically significant in the three specifications. This result indicates that the government policy of implementing real increases in the minimum wage could be an appropriate mechanism for combating income inequality. All specifications show that the coefficient on UNE is statistically significant and has a positive sign. This implies that high unemployment is associated with high inequality. The negative and significant effect of the variable leaves no doubt about the relation between the variables.

The set of variables that incorporates the influence of political factors on inequality shows interesting results. The PC coefficients are contrary to the standard argument that a more frequent change in political power reduces inequality. A possible explanation for this result is that successive political changes can disrupt the continuity of social programmes. Another possible explanation is that when a political party successfully reduces income inequality, it has a higher chance of remaining in power. The positive sign of soc may initially seem contrary to expectations. However, the result is in line with the idea that these resources may not be reaching the poorest families (Feldstein, 1974; Browning and Browning, 1994; Mazza, 2001; Perry and others, 2006). Finally, the CORR coefficients, which are positive and statistically significant in all three models, indicate that an increase in corruption correlates with a worsening in the inequality income. 
TABLE 3

The Gini inequality index: system GMM estimator

\begin{tabular}{|c|c|c|c|c|c|c|c|}
\hline Variable & (1) & (2) & (3) & (4) & (5) & (6) & $(7)$ \\
\hline $\operatorname{Gini}_{i, t-1}$ & $\begin{array}{l}0.3661^{\mathrm{b}} \\
(0.1542) \\
{[2.3728]}\end{array}$ & $\begin{array}{l}0.2312^{\mathrm{c}} \\
(0.1328) \\
{[1.7409]}\end{array}$ & $\begin{array}{c}0.0311 \\
(0.2349) \\
{[0.1323]}\end{array}$ & $\begin{array}{c}0.1436 \\
(0.1679) \\
{[0.8557]}\end{array}$ & $\begin{array}{c}0.3959^{\mathrm{b}} \\
(0.1888) \\
{[-2.0970]}\end{array}$ & $\begin{array}{l}0.2413^{c} \\
(0.1275) \\
{[1.8922]}\end{array}$ & $\begin{array}{l}0.6734^{\mathrm{a}} \\
(0.1583) \\
{[4.2536]}\end{array}$ \\
\hline $\operatorname{OPEN}_{i, t-1}$ & $\begin{array}{c}-0.3450^{\mathrm{a}} \\
(0.0945) \\
{[-3.6483]}\end{array}$ & $\begin{array}{c}-0.3036^{\mathrm{a}} \\
(0.0970) \\
{[-3.1281]}\end{array}$ & $\begin{array}{c}-0.2307^{c} \\
(0.1377) \\
{[-1.6747]}\end{array}$ & $\begin{array}{c}-0.2586^{b} \\
(0.0818) \\
{[-3.1578]}\end{array}$ & $\begin{array}{c}-0.2899^{a} \\
(0.1055) \\
{[-2.7472]}\end{array}$ & $\begin{array}{c}-0.2735^{\mathrm{a}} \\
(0.0801) \\
{[-3.4104]}\end{array}$ & $\begin{array}{c}-0.2812^{b} \\
(0.1083) \\
{[-2.5960]}\end{array}$ \\
\hline $\mathrm{PAT}_{i, t-1}$ & $\begin{array}{c}-0.1815^{\mathrm{c}} \\
(0.0998) \\
{[-1.8189]}\end{array}$ & $\begin{array}{c}-0.2217^{b} \\
(0.1053) \\
{[-2.1061]}\end{array}$ & $\begin{array}{c}-0.1132 \\
(0.0861) \\
{[-1.3146]}\end{array}$ & $\begin{array}{c}-0.1983^{a} \\
(0.0704) \\
{[-2.8172]}\end{array}$ & $\begin{array}{c}-0.2195 \\
(0.1685) \\
{[-1.3027]}\end{array}$ & $\begin{array}{c}-0.2194^{b} \\
(0.0862) \\
{[-2.5435]}\end{array}$ & $\begin{array}{c}-0.1286 \\
(0.1211) \\
{[-1.0614]}\end{array}$ \\
\hline $\mathrm{FD}_{i, t-1}$ & $\begin{array}{c}-0.5812^{c} \\
(0.3196) \\
{[-1.8184]}\end{array}$ & $\begin{array}{c}-0.6857^{\mathrm{b}} \\
(0.3032) \\
{[-2.2617]}\end{array}$ & $\begin{array}{c}-0.6188^{b} \\
(0.2503) \\
{[-2.4715]}\end{array}$ & $\begin{array}{c}-0.3778^{c} \\
(0.2276) \\
{[-1.6603]}\end{array}$ & $\begin{array}{c}-0.6792^{c} \\
(0.3718) \\
{[-1.8265]}\end{array}$ & $\begin{array}{c}-0.4910^{c} \\
(0.2560) \\
{[-1.9179]}\end{array}$ & $\begin{array}{c}-0.2623 \\
(0.3304) \\
{[-0.7940]}\end{array}$ \\
\hline $\mathrm{MW}_{i, t-1}$ & & $\begin{array}{c}-0.0641^{\mathrm{c}} \\
(0.0383) \\
{[-1.6697]}\end{array}$ & & & & & \\
\hline $\mathrm{UNE}_{i, t-1}$ & & & $\begin{array}{l}1.1295^{c} \\
(0.6403) \\
{[1.7638]}\end{array}$ & & & & \\
\hline $\mathrm{BF}_{i, t-1}$ & & & & $\begin{array}{c}-0.2502^{\mathrm{a}} \\
(0.0899) \\
{[-2.7830]}\end{array}$ & & & \\
\hline $\mathrm{PC}_{i, t-1}$ & & & & & $\begin{array}{l}0.0197^{c} \\
(0.0114) \\
{[1.7350]}\end{array}$ & & \\
\hline $\operatorname{CORR}_{i, t-1}$ & & & & & & & $\begin{array}{c}0.0011^{\mathrm{a}} \\
(0.0004) \\
{[2.8408]}\end{array}$ \\
\hline$J$ statistic & $\begin{array}{l}15.7519 \\
p>0.35\end{array}$ & $\begin{array}{l}16.8766 \\
p>0.45\end{array}$ & $\begin{aligned} & 4.3807 \\
& \mathrm{p}>0.95\end{aligned}$ & $\begin{array}{l}17.8650 \\
p>0.45\end{array}$ & $\begin{aligned} & 8.1331 \\
\mathrm{p}> & 0.70\end{aligned}$ & $\begin{array}{l}23.1068 \\
p>0.25\end{array}$ & $\begin{array}{l}14.8607 \\
p>0.35\end{array}$ \\
\hline $\mathrm{m}^{2}$ & -0.0796 & -0.1286 & 0.0789 & -0.1100 & -0.0444 & -0.1144 & -0.0325 \\
\hline$p$ value & 0.6703 & 0.4619 & 0.7726 & 0.5058 & 0.7956 & 0.4712 & 0.8362 \\
\hline Instruments & 20 & 22 & 21 & 23 & 16 & 25 & 19 \\
\hline
\end{tabular}

Source: prepared by the authors.

Note: standard errors are in parentheses; $t$ statistics in brackets.

GMM: generalized method of moments.

a Significant at $1 \%$

b Significant at $5 \%$.

c Significant at $10 \%$. 
TABLE 4

The Theil index: system GMM estimator

\begin{tabular}{|c|c|c|c|c|c|c|c|}
\hline Variable & (1) & (2) & (3) & (4) & (5) & (6) & (7) \\
\hline Theil $_{i, t-1}$ & $\begin{array}{l}0.3181^{\mathrm{a}} \\
(0.1193) \\
{[2.6657]}\end{array}$ & $\begin{array}{l}0.2255^{\mathrm{c}} \\
(0.1356) \\
{[1.6626]}\end{array}$ & $\begin{array}{c}0.0226 \\
(0.2456) \\
{[0.0922]}\end{array}$ & $\begin{array}{l}0.3322^{\mathrm{c}} \\
(0.1735) \\
{[1.9143]}\end{array}$ & $\begin{array}{c}0.1798 \\
(0.1391) \\
{[1.2932]}\end{array}$ & $\begin{array}{c}0.2365^{\mathrm{c}} \\
(0.1378) \\
{[1.7151]}\end{array}$ & $\begin{array}{c}0.2186 \\
(0.2327) \\
{[0.9394]}\end{array}$ \\
\hline $\operatorname{OPEN}_{i, t-1}$ & $\begin{array}{c}-0.4547^{b} \\
(0.2170) \\
{[-2.0950]}\end{array}$ & $\begin{array}{c}-0.7298^{b} \\
(0.2897) \\
{[-2.5188]}\end{array}$ & $\begin{array}{c}-0.7865^{\mathrm{c}} \\
(0.4439) \\
{[-1.7717]}\end{array}$ & $\begin{array}{c}-0.4683^{c} \\
(0.2640) \\
{[-1.7740]}\end{array}$ & $\begin{array}{c}-1.1196^{\mathrm{a}} \\
(0.2870) \\
{[-3.9001]}\end{array}$ & $\begin{array}{c}-0.8191^{\mathrm{a}} \\
(0.2673) \\
{[-3.0640]}\end{array}$ & $\begin{array}{r}-0.6154^{\mathrm{c}} \\
(0.3487) \\
{[-1.7649]}\end{array}$ \\
\hline $\operatorname{PAT}_{i, t-1}$ & $\begin{array}{c}-0.3656^{\mathrm{c}} \\
(0.2069) \\
{[-1.7664]}\end{array}$ & $\begin{array}{c}-0.3671 \\
(0.2517) \\
{[-1.4584]}\end{array}$ & $\begin{array}{c}-0.1386 \\
(0.3377) \\
{[-0.4104]}\end{array}$ & $\begin{array}{c}-0.2108 \\
(0.1652) \\
{[-1.2763]}\end{array}$ & $\begin{array}{c}-0.4275 \\
(0.3680) \\
{[-1.1617]}\end{array}$ & $\begin{array}{c}-0.5312^{c} \\
(0.3005) \\
{[-1.7678]}\end{array}$ & $\begin{array}{c}-0.2733 \\
(0.2936) \\
{[-0.9308]}\end{array}$ \\
\hline $\mathrm{FD}_{i, t-1}$ & $\begin{array}{c}-1.4097^{b} \\
(0.6760) \\
{[-2.0853]}\end{array}$ & $\begin{array}{c}-1.5366^{b} \\
(0.5957) \\
{[-2.5791]}\end{array}$ & $\begin{array}{c}-1.4353^{c} \\
(0.7599) \\
{[-1.8885]}\end{array}$ & $\begin{array}{c}-0.4021 \\
(0.6474) \\
{[-0.6212]}\end{array}$ & $\begin{array}{c}-1.9878^{a} \\
(0.7372) \\
{[-2.6963]}\end{array}$ & $\begin{array}{c}-1.4884^{\mathrm{c}} \\
(0.7821) \\
{[-1.9029]}\end{array}$ & $\begin{array}{r}-1.5142^{\mathrm{c}} \\
(0.7964) \\
{[-1.9012]}\end{array}$ \\
\hline $\mathrm{MW}_{i, t-1}$ & & $\begin{array}{c}-0.1909^{c} \\
(0.1065) \\
{[-1.7914]}\end{array}$ & & & & & \\
\hline $\mathrm{UNE}_{i, t-1}$ & & & $\begin{array}{l}3.4700^{\mathrm{c}} \\
(1.9531) \\
{[1.7766]}\end{array}$ & & & & \\
\hline $\mathrm{BF}_{i, t-1}$ & & & & $\begin{array}{c}-0.4888^{c} \\
(0.2491) \\
{[-1.9624]}\end{array}$ & & & \\
\hline $\mathrm{PC}_{i, t-1}$ & & & & & $\begin{array}{c}0.0516^{\mathrm{b}} \\
(0.0254) \\
{[2.0319]}\end{array}$ & & \\
\hline $\operatorname{soc}_{i, t-1}$ & & & & & & $\begin{array}{c}5.8652^{\mathrm{c}} \\
(3.2236) \\
{[1.8194]}\end{array}$ & \\
\hline $\mathrm{CORR}_{i, t-1}$ & & & & & & & $\begin{array}{c}0.0027^{\mathrm{c}} \\
(0.0015) \\
{[1.7249]}\end{array}$ \\
\hline$J$ statistic & $\begin{array}{l}30.3120 \\
p>0.14\end{array}$ & $\begin{array}{l}23.3662 \\
p>0.35\end{array}$ & $\begin{array}{l}14.6388 \\
p>0.45\end{array}$ & $\begin{array}{l}25.4334 \\
p>0.14\end{array}$ & $\begin{array}{l}12.1678 \\
p>0.80\end{array}$ & $\begin{array}{l}14.0110 \\
p>0.80\end{array}$ & $\begin{aligned} & 9.0667 \\
& p>0.75\end{aligned}$ \\
\hline $\mathrm{m}^{2}$ & -0.1610 & -0.1606 & 0.3007 & -0.1500 & -0.1108 & -0.1755 & -0.1149 \\
\hline$p$ value & 0.5785 & 0.6079 & 0.2603 & 0.6011 & 0.6855 & 0.4884 & 0.6647 \\
\hline Instruments & 27 & 27 & 20 & 24 & 23 & 25 & 18 \\
\hline
\end{tabular}

Source: prepared by the authors.

Note: standard errors are in parentheses; $t$ statistics in brackets. GMM: generalized method of moments.

$\begin{array}{ll}\text { a } & \text { Significant at } 1 \% . \\ \text { b Significant at } 5 \% . \\ \text { c Significant at } 10 \% .\end{array}$ 
TABLE 5

The 10:40 ratio: system GMM estimator

\begin{tabular}{|c|c|c|c|c|c|c|c|}
\hline Variable & (1) & (2) & (3) & (4) & (5) & (6) & (7) \\
\hline $10: 40_{i, t-1}$ & $\begin{array}{l}0.3202^{\mathrm{c}} \\
(0.1651) \\
{[1.9388]}\end{array}$ & $\begin{array}{c}0.2761 \\
(0.1570) \\
{[1.7577]}\end{array}$ & $\begin{array}{c}0.0840 \\
(0.2000) \\
{[0.4203]}\end{array}$ & $\begin{array}{c}0.1089 \\
(0.1408) \\
{[0.7733]}\end{array}$ & $\begin{array}{c}0.1584 \\
(0.1581) \\
{[1.0015]}\end{array}$ & $\begin{array}{l}0.3354^{b} \\
(0.1337) \\
{[2.5085]}\end{array}$ & $\begin{array}{c}0.4430^{b} \\
(0.1869) \\
{[2.3695]}\end{array}$ \\
\hline $\operatorname{OPEN}_{i, t-1}$ & $\begin{array}{c}-0.2878^{a} \\
(0.0856) \\
{[-3.3601]}\end{array}$ & $\begin{array}{c}-0.3318^{b} \\
(0.0881) \\
{[-3.7663]}\end{array}$ & $\begin{array}{c}-0.2465^{b} \\
(0.1201) \\
{[-2.0519]}\end{array}$ & $\begin{array}{c}-0.1607^{b} \\
(0.0636) \\
{[-2.5247]}\end{array}$ & $\begin{array}{c}-0.3259^{\mathrm{a}} \\
(0.0932) \\
{[-3.4957]}\end{array}$ & $\begin{array}{c}-0.1482^{b} \\
(0.0659) \\
{[-2.2482]}\end{array}$ & $\begin{array}{c}-0.3721^{\mathrm{a}} \\
(0.0840) \\
{[-4.4301]}\end{array}$ \\
\hline $\operatorname{PAT}_{i, t-1}$ & $\begin{array}{c}-0.1512^{\mathrm{c}} \\
(0.0771) \\
{[-1.9609]}\end{array}$ & $\begin{array}{c}-0.1893^{b} \\
(0.1081) \\
{[-1.7511]}\end{array}$ & $\begin{array}{c}-0.1182 \\
(0.1070) \\
{[-1.1051]}\end{array}$ & $\begin{array}{c}-0.1827^{\mathrm{a}} \\
(0.0639) \\
{[-2.8562]}\end{array}$ & $\begin{array}{c}-0.2285^{\mathrm{c}} \\
(0.1332) \\
{[-1.7145]}\end{array}$ & $\begin{array}{c}-0.1670^{\mathrm{c}} \\
(0.0865) \\
{[-1.9301]}\end{array}$ & $\begin{array}{c}-0.1368 \\
(0.1076) \\
{[-1.2707]}\end{array}$ \\
\hline $\mathrm{FD}_{i, t-1}$ & $\begin{array}{c}-0.3983^{c} \\
(0.2289) \\
{[-1.7399]}\end{array}$ & $\begin{array}{c}-0.7164^{b} \\
(0.3438) \\
{[-2.0838]}\end{array}$ & $\begin{array}{c}-0.6747^{b} \\
(0.3047) \\
{[-2.2141]}\end{array}$ & $\begin{array}{c}-0.1495 \\
(0.1864) \\
{[-0.8020]}\end{array}$ & $\begin{array}{c}-0.6786^{b} \\
(0.2797) \\
{[-2.4257]}\end{array}$ & $\begin{array}{c}-0.4622^{c} \\
(0.2485) \\
{[-1.8600]}\end{array}$ & $\begin{array}{c}-0.1130 \\
(0.2864) \\
{[-0.3946]}\end{array}$ \\
\hline $\mathrm{MW}_{i, t-1}$ & & $\begin{array}{c}-0.0684^{\mathrm{c}} \\
(0.0365) \\
{[-1.8727]}\end{array}$ & & & & & \\
\hline $\mathrm{UNE}_{i, t-1}$ & & & $\begin{array}{c}0.9448^{\mathrm{c}} \\
(0.5678) \\
{[1.6639]}\end{array}$ & & & & \\
\hline $\mathrm{BF}_{i, t-1}$ & & & & $\begin{array}{c}-0.2582^{\mathrm{a}} \\
(0.0820) \\
{[-3.1482]}\end{array}$ & & & \\
\hline $\mathrm{PC}_{i, t-1}$ & & & & & $\begin{array}{l}0.0219^{b} \\
(0.0105) \\
{[2.0787]}\end{array}$ & & \\
\hline $\operatorname{SOC}_{i, t-1}$ & & & & & & $\begin{array}{c}0.0568 \\
(0.7209) \\
{[0.0788]}\end{array}$ & \\
\hline $\mathrm{CORR}_{i, t-1}$ & & & & & & & $\begin{array}{l}0.0012^{\mathrm{a}} \\
(0.0004) \\
{[2.9981]}\end{array}$ \\
\hline$J$ statistic & $\begin{array}{l}21.5093 \\
p>0.25\end{array}$ & $\begin{array}{l}13.7063 \\
p>0.80\end{array}$ & $\begin{array}{l}11.1198 \\
\mathrm{p}>0.85\end{array}$ & $\begin{array}{l}26.5805 \\
\mathrm{p}>0.14\end{array}$ & $\begin{array}{l}14.5990 \\
\mathrm{p}>0.65\end{array}$ & $\begin{array}{l}27.1170 \\
\mathrm{p}>0.15\end{array}$ & $\begin{aligned} & 8.7405 \\
\mathrm{p} & >0.80\end{aligned}$ \\
\hline $\mathrm{m}^{2}$ & -0.0359 & -0.0637 & 0.1127 & -0.0800 & -0.0119 & -0.0573 & 0.0274 \\
\hline$p$ value & 0.8297 & 0.7042 & 0.6239 & 0.5891 & 0.9375 & 0.7123 & 0.8536 \\
\hline Instruments & 23 & 24 & 22 & 25 & 23 & 26 & 19 \\
\hline
\end{tabular}

Source: prepared by the authors.

Note: standard errors are in parentheses; $t$ statistics in brackets. GMM: generalized method of moments.

a Significant at $1 \%$.

b Significant at $5 \%$.

c Significant at $10 \%$.

\section{IV}

\section{Conclusion}

This study has presented empirical evidence regarding income inequality in the Brazilian economy. The regional analysis showed that there are considerable differences across the country. In general, the south has the lowest income inequality and best indicators. In contrast, the northeast recorded the worst performance over time. However, the introduction of social policies, such as Bolsa Família, is associated with an improvement in all regions. 
The results of the empirical analysis indicate that there are several factors that can explain the recent fall in inequality in Brazil. An example is trade openness. As highlighted by Rodrik (2007), Easterly (2005) and Nissanke and Thorbecke (2006), in economies that have a labour-intensive export sector, such as Brazil, an increase in the trade openness contributes to an improvement in income inequality. Consequently, expanding trade agreements and enhancing tax harmonization to improve trade openness could provide a mechanism for addressing inequality. The results further indicate that an increase in technological progress implies lower income inequality, in line with Acemoglu's (2002) argument. Greater financial development is also correlated with reductions in inequality (Liang, 2006; Ang, 2010). Hence, recommended policies include increasing partnerships between companies and universities and fostering a legal environment capable of stimulating private sector investment in technology.

The Government of Brazil's strategy of implementing real increases in the minimum wage over time is negatively correlated with inequality. In contrast, unemployment increases inequality, so the adoption of policies for eliminating unemployment is crucial. In addition, the results show that the Bolsa Família programme is associated with decreases in income inequality.

The empirical evidence on the effect of political factors on inequality indicates that a change in political power does not contribute to an improvement in the social condition. Similarly, an increase in social spending does not decrease income inequality. One possible explanation is that these resources do not reach the poorest families (Feldstein, 1974; Browning and Browning, 1994; Mazza, 2001; Perry and others, 2006). The use of specific tools against poverty could produce better results. Finally, the Brazilian case confirms the assumption that higher corruption correlates with an increase in inequality (Gupta, Davoodi and Alonso-Terme, 2002).

In short, the empirical evidence in this study allows one to observe that it is possible to improve the fight against inequality through a combination of increased trade openness, technological and financial development, the reduction of the unemployment rate, the adoption of social policies that have a direct effect on the poorest families and the adoption of mechanisms that restrict corruption.

\section{Bibliography}

Acemoglu, D. (2002), "Technical change, inequality, and the labor market", Journal of Economic Literature, vol. 40, No. 1, Nashville, Tennessee, American Economic Association.

Acemoglu, D. and A. Newman (2002), "The labour market and corporate structure", European Economic Review, vol. 46, No. 10, Amsterdam, Elsevier.

Adams, S. (2008), "Globalization and income inequality: implications for intellectual property rights", Journal of Policy Modeling, vol. 30, No. 5, Amsterdam, Elsevier.

Adelman, I. and C. Morris (1965), "A factor analysis of the interrelationship between social and political variables and per capita gross national product", Quarterly Journal of Economics, vol. 79, No. 4, Oxford, Oxford University Press.

Aghion, P. and P. Bolton (1997), "A theory of trickle-down growth and development", Review of Economic Studies, vol. 64, No. 2, Wiley Blackwell.

Alonso-Borrego, C. and M. Arellano (1998), "Symmetrically normalized instrumental-variable estimation using panel data", CEMFI Working Paper, No. 9612, September.

Alt, J. and D. Lassen (2010), "Enforcement and public corruption: evidence from US states", EPRU Working Paper Series, No. 2010-08, Copenhagen, University of Copenhagen.

Ang, J.B. (2010), "Finance and inequality: the case of India", Southern Economic Journal, vol. 76, No. 3, Southern Economic Association.

Apergis, N., O.C. Dincer and J. Payne (2010), "The relationship between corruption and income inequality in U.S. states: evidence from a panel cointegration and error correction model", Public Choice, vol. 145, No. 1, Springer.

Arellano, M. (2003), Panel Data Econometrics, Oxford, Oxford University Press.
Arellano, M. and S. Bond (1991), "Some tests of specification for panel data: Monte Carlo evidence and an application to employment equations", Review of Economic Studies, vol. 58, No. 2, Oxford, Oxford University Press.

Arellano, M. and O. Bover (1995), "Another look at the instrumental variable estimation of error-components model", Journal of Econometrics, vol. 68, No. 1, Amsterdam, Elsevier.

Blinder, A.S. and H.Y. Esaki (1978), "Macroeconomic activity and income distribution in the postwar United States", Review of Economics and Statistics, vol. 60, No. 4, Cambridge, Massachusetts, The MIT Press.

Blundell, R. and S. Bond (1998), "Initial conditions and moment restrictions in dynamic panel data models", Journal of Econometrics, vol. 87, No. 1, Amsterdam, Elsevier.

Boll, J.L.S. (2010), "A corrupção governamental no Brasil: construção de indicadores e análise da sua incidência relativa nos estados brasileiros", Brasilia [online] http://www.cgu.gov.br/concursos/ Arquivos/5_ConcursoMonografias/MH-profissionais-jose-luisserafini-boll.pdf.

Bond, S.R., A. Hoeffler and J. Temple (2001), "GMM estimation of empirical growth models”, CEPR Discussion Paper, No. 3048, London, Centre for Economic Policy Research.

Browning, E. and J.M. Browning (1994), Public Finance and the Price System, Englewood Cliffs, Prentice Hall.

Claessens, S. and E. Perotti (2005), "The links between finance and inequality: channels and evidence", World Development Report Background Papers, Washington, D.C., World Bank.

Dincer, O.C. and B. Gunalp (2008), "Corruption, income inequality and poverty in the United States", Nota di lavoro, No. 54, Fondazione Eni Enrico Mattei. 
Easterly, W. (2005), "National policies and economic growth: a reappraisal", Handbook of Economic Growth, Philippe Aghion and Steven Durlauf (eds.), Amsterdam, Elsevier.

Engel, E., A. Galetovic and C. Raddatz (1999), "Taxes and income distribution in Chile: some unpleasant redistributive arithmetic", Journal of Development Economics, vol. 59, No. 1, Amsterdam, Elsevier

Fang, C., L. Huang and M. Wang (2008), "Technology spillover and wage inequality", Economic Modelling, vol. 25, No. 1, Amsterdam, Elsevier.

Feldstein, M. (1974), "Social security, induced retirement, and aggregate capital accumulation", Journal of Political Economy, vol. 82, No. 5, Chicago, The University of Chicago Press.

Forteza, A. and I. Rossi (2009), "The contribution of government transfer programs to inequality: A net-benefit approach", Journal of Applied Economics, vol. 12, No. 1, Amsterdam, Elsevier.

Galor, O. and J. Zeira (1993), "Income distribution and macroeconomics", Review of Economic Studies, vol. 60, No. 1, Blackwell Wiley.

Gasparini, L. (2003), "Different lives: inequality in Latin America the Caribbean", Inequality the State in Latin America and the Caribbean, Washington, D.C., World Bank.

Goñi, E., J. López and L. Servén (2011), "Fiscal redistribution and income inequality in Latin America", World Development, vol. 39, No. 9, Amsterdam, Elsevier.

Greenwood, J. and B. Jovanovic (1990), "Financial development, growth and, the distribution of income", Journal of Political Economy, vol. 98, No. 5, Chicago, The University of Chicago Press.

Gupta, S., H. Davoodi and R. Alonso-Terme (2002), "Does corruption affect income inequality and poverty?", Economics of Governance, vol. 3, No. 1, Springer.

Kumar, A. (2005), "Access to financial services in Brazil", Directions in Development, Washington, D.C., World Bank.

Lemos, S. (2009), "Minimum wage effects in a developing country", Labour Economics, vol. 16, No. 2, Amsterdam, Elsevier.

Levitt, S. and J. Poterba (1999), "Congressional distributive politics and state economic performance", Public Choice, vol. 99, No. 1-2, Springer.
Liang, Z. (2006), "Financial development and income distribution: a system GMM panel analysis with application to urban China", Journal of Economic Development, vol. 31, No. 2.

Madsen, J. (2007), "Technology spillover through trade and TFP convergence: 135 years of evidence for the OECD countries", Journal of International Economics, vol. 72, No. 2, Amsterdam, Elsevier.

Martínez, R., L. Ayala and J. Ruiz-Huerta (2001), "The impact of unemployment on inequality and poverty in OECD countries", Economics of Transition, vol. 9, No. 2, London, European Bank for Reconstruction and Development.

Mazza, J. (2001), "Unemployment insurance: case studies and lessons for Latin America and the Caribbean", Working Paper, No. 411, Washington, D.C., Research Department, Inter-American Development Bank.

Meschi, E. and M. Vivarelli (2009), "Trade and income inequality in developing countries", World Development, vol. 37, No. 2, Amsterdam, Elsevier.

Nissanke, M. and H. Thorbecke (2006), "Channels and policy debate in the globalization-inequality-poverty nexus", World Development, vol. 34, No. 8, Amsterdam, Elsevier.

Perry, G. and others (2006), Poverty Reduction and Growth: Virtuous and Vicious Circles, Washington, D.C., World Bank.

Rodrik, D. (1997), Has Globalization Gone Too Far?, Washington, D.C., Institute for International Economics.

Roine, J., J. Vlachos and D. Waldenström (2009), "The long-run determinants of inequality: what can we learn from top income data?", Journal of Public Economics, vol. 93, No. 7-8, Amsterdam, Elsevier.

Rupasingha, A. and S. Goetz (2007), "Social and political forces as determinants of poverty: a spatial analysis", Journal of SocioEconomics, vol. 36, No. 4, Amsterdam, Elsevier.

Staiger, D. and J.H. Stock (1997), "Instrumental variables regression with weak instruments", Econometrica, vol. 65, No. 3, New York, The Econometric Society.

Wooldridge, J. (2001), Econometric Analysis of Cross Section and Panel Data, Cambridge, Massachusetts, The MIT Press. 